\title{
A Study of Power Relations in Doctor-Patient Interactions in Selected Hospitals in Lagos State, Nigeria
}

\author{
Qasim Adam \\ Department of English, University of Lagos, Nigeria \\ E-mail:mqradam@gmail.com
}

Doi:10.7575/aiac.alls.v.5n.2p.177

Received: 03/03/2014

URL: http://dx.doi.org/10.7575/aiac.alls.v.5n.2p.177

Accepted: 16/04/2014

\begin{abstract}
This paper explores power relations in clinical interactions in Nigeria. It seeks to investigate the use of power between doctors and patients during consultations on patient-centred approach to medicine in selected public and private hospitals in Lagos State, Nigeria. The objective is to establish how doctors' projection of power, using the discourse resources of transitivity, affects positively or negatively their relationship with patients. This study employs triangulation as its methodology. A judicious mix of quantitative and qualitative methods has been utilized to give the study a scientific shape. Proportionate stratified random sampling and purposive sampling procedures were employed. The study employs the theoretical and analytical paradigms of Systemic Functional Linguistics and Critical Discourse Analysis. The findings revealed that doctors predominantly use this process to the benefit of the patients. Minimal level of intrusive and cooperative interruptions was also observed. It is expected that this study will give more visibility on the best way patients can be empowered by lessening doctors' use of polar interrogatives and completely avoiding interruptive discourse in clinical interactions.
\end{abstract}

Keywords: Discourse Analysis, Power Relations, Transitivity, Doctor-Patient Interactions

\section{Introduction}

This study is an exploration of the use of the discourse resources of transitivity as deployed in the enactment of power in doctor-patient interactions in selected public and private hospitals in Lagos State, Nigeria. Issues of power in clinical encounters have been linked to the problem of imbalance in the discourse of the participants; hence, the study examines how the doctor's use of power supports or negates the principles of patient-centredness in medical consultations. Using the theoretical and analytical parameters of Systemic Functional Linguistics (SFL) and Critical Discourse Analysis (CDA), this study examines how the discourse roles of interactants reveal the dynamics of power projection in clinical encounters (transitivity).

\subsection{Background to the Study}

Studies on interpersonal communication in medical encounters confirm that doctor-patient rapport is key to effective health care delivery (Kurz et al, 2003). Patients' physical wellbeing is highly dependent on effective technical knowledge backed up by a robust and effective interpersonal communication (Ambady et al, 2002). Power relation is a pervasive phenomenon in social life and language, being an inalienable part of our social life, possesses multifarious ways of exhibiting power. As Kress (1982) observes '...language is entwined in social power in a number of ways: it indexes power, expresses power, and language is involved wherever there is contention over and challenge to power'. Again, studies have revealed that when doctors misuse their power within the doctor-patient encounter, patients' attitude towards doctors, health care, and in how they perceive themselves are adversely affected ( Gridley et al , cited in Polimeni, 2004). Clinical encounters have the fertile potential for social power abuse so also is patients consent to the doctor's authority and advice because of the doctor's gate-keeping monopoly over matters such as surgery, prescriptions, insurance, and sick leave (Friedson, 1970). Medicine is a social act and at the heart of effective diagnosis and treatment lies interaction between doctors and patients. A good rapport between doctors and patients is indispensable for a healthy society. This is evidenced by the fact that doctors conduct a mean of 120,000 to 160,000 interviews with patients in a practice lifetime (Lipkin et al, 1995). According to the American Medical Association (AMA) Code of Medical Ethics (1847), the life of a sick person can be shortened not only by the acts, but also by the words and the manner of a physician.

\subsection{Objective of the Study}

The objective of this study is to investigate the role of transitivity options of power projection in doctor-patient interactions in Lagos State, Nigeria.

\subsection{Statement of the Problem}

A catalogue of studies has been done on doctor-patient interactions. For instance, the use of questions to claim power (Frankel, 1992); problem presentation stage of medical talk (Ruusuvuori, 2000); diagnostic stage of medical interaction (Heath, 1992); opening stage of medical encounters (Robinson and Heritage, 2006); topic transition (Ainsworth- 
Vaughn, 2001); the structure of medical consultation (Byne and Long, 1976) and women powerlessness in medical interactions (Polimeni, 2004). Most of these studies were done outside the theoretical and analytical frameworks of Systemic-Functional Linguistics and Critical Discourse Analysis. This study hopes to fill in this gap by taking an indepth look at power relations in doctor-patient interactions using the theoretical lens of SFL and CDA. Moreover, transitivity analysis of institutional talk has been described as "a novel enterprise" because previous studies "tended to concentrate entirely on written texts" (Shimazumi, 1996) including fiction (Gregory et al, 1988) or non-fiction (Francis and Kramer-Dahl, 1992).

In Nigeria, studies on medical discourse are still in the infancy stage (Adegbite and Odebunmi, 2006). According to Odebunmi (2006), most studies on medical discourse in Nigeria have focused on the register, and the "pragmatics of the discourse" e.g. Ogunbode (1991) and Odebunmi (2003, 2006) and none of these works has adopted SFL analytical parameters nor have they employed an elaborate quantitative methodology. Hence this study attempts to fill in the theoretical and analytical gaps left by these studies by applying SFL and CDA paradigms in its exploration of power relations in doctor-patient interactions as well as deploy a mix of qualitative and quantitative methodology.

Moreover, clinical consultations have often been criticized for being too paternalistic or doctor-centred. In this model, doctors see patients as cases or diagnosis rather than as persons. Doctors focus on symptoms but ignore the psychosocial context of the patients and their conditions. According to van Weel-Baumgarten (2010), "the doctor does most of the talking and takes decisions on diagnosis and treatment, without shared responsibility and decision-making" This strict bio-medical approach may breed negative outcomes such as low compliance by patients and social power abuse by doctors. Better outcomes can be achieved with a patient-centred clinical interaction. This study aims to critically analyze doctor- patient interactions in order to account for linguistic elements which negate or support patientcentredness in medical encounters in Lagos State, Nigeria.

\section{Theoretical Framework}

In this study, two theories were employed: Systemic Functional Linguistics (SFL) and Critical Discourse Analysis (CDA).

\subsection{Systemic Functional Linguistics (SFL)}

SFL is a tristratal construct of semantics (meaning), lexico-grammar (wording), and phonology (sound) which constitute a semiotic system. According to Eggins (2004), (Systemic), systemic linguists make four main theoretical claims about language: (a) That language use is functional; (b) That its function is to make meaning; (c) That meaning is influenced by social and cultural contexts; and (d) That the process of using language is a semiotic process in which people make meanings by making linguistic choices.

\subsection{Critical Discourse Analysis (CDA)}

CDA is a political school of discourse analysis whose major agenda is in "identifying how language contributes to power imbalances in society and how analysis of this might contribute to change in favour of the oppressed (Ward, 2004)). CDA aims to remove false or distorted consciousness and to render transparent what had been previously hidden from public consciousness by initiating a process of self-reflection in individuals and groups. CDA has a deconstructive agenda and is concerned with exposing language deployed in the service of power.

\section{Methodology}

\subsection{Triangulation}

In this study, we adopted the concept of triangulation. Triangulation is the use of multiple methods in the study of the same object. According to Wolfram-Cox and Hassard (2005), the implicit assumption in using triangulation "is of developing a more effective method for capturing and fixing of social phenomena in order to realize a more accurate analysis and explanation". Since "different methods have different strengths and weaknesses" (Gillham, 2000) the "effectiveness of triangulation rests on the premise that the weakness in each single method will be compensated by the counter-balancing strengths of another" (Jick, 1979). Hence, triangulation can potentially elevate researchers above personal biases that emanate from a single methodology.

\subsection{Types of Triangulation Used in this Study}

In this study, three types of triangulation have been employed: (a) data triangulation, (b) theory triangulation, and (c) methodological triangulation.

(a) Data triangulation: This involves collecting and using data from male, female, young, old patients as well as male and female doctors in private and public hospitals in different parts of Lagos.

(b) Theory triangulation: SFL and CDA have been employed as theoretical tools.

(c) 'Methodological triangulation: "between" method triangulation is used whereby the following mix of qualitative and quantitative sampling procedures is employed: (i) Probability Sampling Technique (Proportionate Stratified Random Sampling); (ii) Non- Probability sampling Technique (Purposive Sampling) 


\subsection{Data Collection Procedure}

The data which constitute the focus of this study were drawn from audio recordings of spoken interactions between doctors and patients in selected private and public hospitals in Lagos State. It is the interactional record of face-to-face conversation between patients and General Practitioners (GPs). Routine interactions between GPs and patients were audio-taped and transcribed.

Non-participant observation was adopted. This is often used to study focused aspects of a setting, to answer specific questions within a study. Hence, "it can thus be a powerful tool in triangulation" (Savenye \& Robinson, 2004). Nonparticipant observation was chosen as the appropriate data collection method because the use of participant observation in close clinical setting may lead to what Stubbs (1983) calls observers' paradox, which simply means that when an observer is physically present at a location, people being observed may put up artificial behaviour. This is highly likely in a medical setting where sensitive matters are topical and of ethical concerns.

\subsection{Sources of Data}

Two selected hospitals were used for this study: (a) University of Lagos Health Centre (Public) and (b) R-Jolad Hospital, Gbagada, Lagos (Private)

\section{Data Analysis and Findings}

\subsection{Role Projection}

\section{(1) Dominant processes uttered by the doctor and the patient}

Table 1. Use of processes by doctor and patient

\begin{tabular}{|l|l|l|l|l|l|}
\hline PROCESS & DOCTOR & $\%$ & PATIENT & \% & TOTAL \\
\hline Material & 102 & $80.3 \%$ & 25 & $19.7 \%$ & 127 \\
\hline Relational & 54 & $63.5 \%$ & 31 & $36.5 \%$ & 85 \\
\hline Mental & 30 & $76.9 \%$ & 9 & $23.1 \%$ & 39 \\
\hline Verbal & 19 & $70.4 \%$ & 8 & $29.6 \%$ & 27 \\
\hline Behavioural & 6 & $75 \%$ & 2 & $25 \%$ & 8 \\
\hline Existential & 5 & $100 \%$ & 0 & $0 \%$ & 5 \\
\hline & $216(74.2 \%)$ & & $75(25.8 \%)$ & & 291 \\
\hline
\end{tabular}

The dominant processes in the data are material, relational, and mental. The doctor utters $80.3 \%$ of material process in all the data while the patient utters $19.7 \%$. Of the 85 relational processes uttered by both doctor and patient across the five data, the doctor uttered $54(63.5 \%)$ while the patient uttered 31 (36.5\%). For mental processes, of the 39 used across the five data, the doctor used 30 representing $77 \%$ of the total while the patient uttered 9 representing $23 \%$ of the total. This shows again the doctor dominating the use of the major transitivity systems. The total number of the minor processes (verbal, behavioural and existential) amounts to $39(13.4 \%)$ across the five data. The doctor also dominates them by uttering 30 processes representing $77 \%$ while the patient has $23 \%$. Overall across the five data, 291 processes were uttered by both doctor and patient. The doctor used 216 processes representing $74.2 \%$ of the total while the patient uttered 75 processes representing $25.8 \%$ of the total. Hence, the percentage difference reveals that in terms of transitivity, the doctor apparently has the upper hand enabling him/her to control the course of the interaction.

\section{(2) Difference in the dominant processes used by doctor and patient}

The material processes uttered by the doctor $(80.3 \%)$ differ significantly more than that used by the patient $(19.7 \%)$. There is also a significant percentage difference between the relational processes uttered by the doctor $(63.5 \%)$ and the patient (36.5\%). However, there is no major difference between the mental processes used by doctors $(76.9 \%)$ and those of patient $(23.1 \%)$. This shows that both the doctor and the patient do a lot of thinking exercise in the course of the encounter. The doctor also seems to have responded well to the patients' emotional needs in the encounter. Both interactants used most of the process types (material, mental, relational, verbal, and behavioural). From CDA standpoint, the patient is given a voice to express her views and concerns in the encounter.

\section{(3) Mutual role projection by doctor and patient}

This has to do with who projects whom in which roles? To answer the question, it is necessary to account for two types of role projections: projection by doctor and projection by patient. According to Table 2 below, the Doctor projects the Patient considerably more often (83.3\%) than herself (16.7\%). The Doctor projects the Patient more as Actor, Goal, Senser, Carrier, and Sayer. This is indicated by the percentage differences.

Table 2. Projection by Doctor

\begin{tabular}{|l|l|l|l|}
\hline ROLES & ABOUT DOCTOR & ABOUT PATIENT & N \\
\hline Actor & $15(14 \%)$ & $92(86 \%)$ & $107(100 \%)$ \\
\hline Goal & $5(6.5 \%)$ & $71(93.5 \%)$ & $76(100 \%)$ \\
\hline
\end{tabular}




\begin{tabular}{|l|l|l|l|}
\hline Beneficiary & $1(16.7 \%)$ & $5(83.3 \%)$ & $6(100 \%)$ \\
\hline Senser & $19(55.9 \%)$ & $15(44.1 \%)$ & $34(100 \%)$ \\
\hline Phenomenon & $1(14.3 \%)$ & $6(85.7 \%)$ & $7(100 \%)$ \\
\hline Sayer & $3(18.8 \%)$ & $13(81.2 \%)$ & $16(100 \%)$ \\
\hline Receiver & $1(9.1 \%)$ & $10(90.9 \%)$ & $11(100 \%)$ \\
\hline Carrier & $2(8.7 \%)$ & $21(91.3 \%)$ & $23(100 \%)$ \\
\hline Behaver & $0(0 \%)$ & $2(100 \%)$ & $2(100 \%)$ \\
\hline $\mathrm{N}$ & $47(16.7 \%)$ & $235(83.3 \%)$ & $282(100 \%)$ \\
\hline
\end{tabular}

As indicated in Table 3 below, the Patient projects himself (85.90\%) significantly more than he projects the Doctor $(14.10 \%)$. These figures show that the general trend of the interactions focuses on the Patient. The Patient is so much consumed by her own condition that most of the major transitivity roles of Actor, Goal, Senser, Sayer and Carrier are heavily allocated to himself leaving little for the Doctor.

Table 3. Projection by Patient

\begin{tabular}{|l|l|l|l|}
\hline ROLES & ABOUT DOCTOR & \multicolumn{1}{|c|}{ ABOUT PATIENT } & \multicolumn{1}{|c|}{ N } \\
\hline Actor & $2(9.1 \%)$ & $20(90.9 \%)$ & $22(100 \%)$ \\
\hline Goal & $3(23.0 \%)$ & $10(76.9 \%)$ & $13(100 \%)$ \\
\hline Beneficiary & $1(20 \%)$ & $4(80 \%)$ & $5(100 \%)$ \\
\hline Senser & $1(10 \%)$ & $9(90 \%)$ & $10(100 \%)$ \\
\hline Phenomenon & $0(0 \%)$ & $0(0 \%)$ & $0(0 \%)$ \\
\hline Sayer & $2(28.6 \%)$ & $5(71.4 \%)$ & $7(100 \%)$ \\
\hline Receiver & $1(25 \%)$ & $3(75 \%)$ & $4(100 \%)$ \\
\hline Carrier & $1(6.25 \%)$ & $15(93.75 \%)$ & $16(100 \%)$ \\
\hline Behaver & $0(0 \%)$ & $1(100 \%)$ & 1 \\
\hline $\mathrm{N}$ & $11(14.10 \%)$ & $67(85.90 \%)$ & $78(100 \%)$ \\
\hline
\end{tabular}

(4) Differences in role projection for Doctor and Patient in each interactant's speech

Table 4. Projection of Doctor

\begin{tabular}{|l|l|l|l|}
\hline ROLES & BY DOCTOR & BY PATIENT & N \\
\hline Actor & $15(88.2 \%)$ & $2(11.8 \%)$ & $17(100 \%)$ \\
\hline Goal & $7(87.5 \%)$ & $1(12.5 \%)$ & $8(100 \%)$ \\
\hline Senser & $19(95 \%)$ & $1(5 \%)$ & $20(100 \%)$ \\
\hline Sayer & $3(60 \%)$ & $2(40 \%)$ & $5(100 \%)$ \\
\hline Carrier & $2(66.72 \%)$ & $1(33.32 \%)$ & $3(100 \%)$ \\
\hline Behaver & $0(0 \%)$ & $0(0 \%)$ & $0(0 \%)$ \\
\hline N & $46(88.8 \%)$ & $7(7.5 \%)$ & $53(100 \%)$ \\
\hline
\end{tabular}

It is important to show the difference in the way transitivity roles are projected for Doctor and Patient in individual interactant's utterances. Table 4 reveals the projection of Doctor in individual transitivity roles in the utterances of each discourse participant. Accordingly, the Doctor is projected by herself $(88.8 \%)$ much more than by the Patient $(7.5 \%)$. This difference is particularly significant for the roles of Actor, Goal and Senser.

Table 5. Projection of Patient

\begin{tabular}{|l|l|l|c|}
\hline ROLES & \multicolumn{1}{|c|}{ BY DOCTOR } & \multicolumn{1}{c|}{ BY PATIENT } & N \\
\hline Actor & $92(82.14 \%)$ & $20(17.86 \%)$ & $112(100 \%)$ \\
\hline Goal & $71(87.65 \%)$ & $10(12.35 \%)$ & $81(100 \%)$ \\
\hline Senser & $15(62.5 \%)$ & $9(37.5 \%)$ & $24(100 \%)$ \\
\hline Sayer & $13(72.3 \%)$ & $5(27.7 \%)$ & $18(100 \%)$ \\
\hline Carrier & $21(58.3 \%)$ & $15(41.7 \%)$ & $36(100 \%)$ \\
\hline Behaver & $2(66.7 \%)$ & $1(33.3 \%)$ & $3 \quad(100 \%)$ \\
\hline N & $214(78.10 \%)$ & $60(21.90 \%)$ & $274(100 \%)$ \\
\hline
\end{tabular}

Table 5 reveals that the projection of the patient significantly differs across interactants. The Patient is highly projected by the Doctor (78.10\%) which is considerably different from the Patient's projection of himself $(21.90 \%)$. This uneven distribution across speakers runs through all the major transitivity roles of Actor, Goal, Senser, Sayer, Carrier and Behaver. The implication of this in the medical practice is that the patient is put at the core of the 
consultation. The considerable difference in role projection for both interactants in each other's speech is in favour of the Patient and good for medical practice. We are therefore led to hypothesize, following Shimazumi's (1996) assertion that 'the Doctor will project roles for herself and patient, the patient will be projecting primarily her own role'.

\subsection{Role Allocation}

The roles that social actors are given to play in representations play a major part in the studies of many critical linguists (e.g. Fowler et al, 1979 and van Dijk, 2009). Role allocation refers to "who is represented as 'agent' (Actor), who is 'patient' (Goal) with respect to a given action (van Leeuwen, 1996). Activation and passivation are the key elements in role allocation. Activation happens when social actors are portrayed as the active, dynamic forces in an activity while passivation occurs when social actors are represented as 'undergoing' the activity or are at the receiving end of it (van Leeuween, 1996). Transitivity structures activate and passivate social actors by giving them grammatical participant roles coded as Actor in material processes, Behaver, in behavioural processes, Senser in mental processes, Sayer in verbal processes or Assigner in relational processes (Halliday, 2004). An example of activation from our data is:

(a) Pt: Eh well, $\boldsymbol{I}$ just want to know my condition again (Hypertension, 4)

An examples of passivation is:

(b) Dr: I want to change you from Nifedripin to Thiapril (Hypertenslon,

In (a), the active agent is the patient while in (b), it is the doctor. The patient is the passive agent in (b). Taking Table 2 into consideration, of the 107 allocations of Actor role in the doctor's utterances, $14 \%$ (15) is allocated to the doctor while $86 \%$ (92) is assigned to the patient. The role of Goal for the patient is $97.3 \%$ (71), while the doctor allocates $(2.7 \%)$ to himself. This is because he is not the focus of the encounter. As for the role of Senser, the doctor allocated $55.9 \%$ to himself, while assigning $44.1 \%$ to the patient. $1 \mathrm{t}$ appears the doctor tends to assert his superior mental ability and activity in the encounter. Obviously, as the moderator-in-chief of the consultation, a lot of thinking and knowledge is needed to make it an optimal success. For the role of the Sayer, the doctor allocates $81.2 \%$ to the patient while $18.8 \%$ is assigned to himself. This is good news because it portrays the patient as someone who has 'said', 'told', 'asked' and 'explained' something in the interaction.

How does the patient allocate roles in her utterances? Readings from Table 3 show that the patient allocates $90.9 \%$ (20) of the role of Actor to himself, while giving $9.1 \%$ to the doctor. The patient also makes himself the Goal of his utterances $90.9 \%$ (10) while assigning $9.1 \%$ (1) to the doctor. As a Senser, the patient assigns 90\% (9) of the utterances to himself, giving the doctor a paltry $10 \%$ (1). As a Sayer, the patient has $71.4 \%$ (5) while the doctor has $28.6 \%$ (2). These figures confirm that the most activated or active participant in the interaction is undoubtedly the patient.

In our data (Hypertension), the doctor constructs the patients as the main actor. The patient is the Agent (actor acting on things). The patient "have been using" drugs (12), "should consider changing" drugs (14), "can afford a thousand five hundred" on drugs (16), should "buy a month's dose" (23), "use Aldomet" (47) "bring your drug" (61) "collect the drugs" (69). The patient represents himself as "just want to know" his condition (4), "don't have any problem" with drugs (6), but "don't have enough" (8). The patient is "afraid" (11), but "thank God that there is no injury" (42), because "that would be very sad" (43), and he "would feel bad" (45). The patient is "just using" drug (53) but "don't know the name" (63).

\subsection{Exclusion}

According to Van Leeuwen (1996), exclusion is "an important aspect of Critical Discourse Analysis". Powerful social actors exclude the less powerful from discourse events or texts to serve their own parochial agenda especially if such exclusions leave no trace of their activities. He postulates two main types of exclusion - suppression and backgrounding. Suppression operates when "there is no reference to the social actor(s) in question anywhere in the text". In the case of backgrounding, "the excluded social actors may not be mentioned in relation to a given activity, but they are mentioned elsewhere in the text". Suppression is realized in a text through passive agent deletion. Perhaps because of the real time and face-to-face dialogic nature of doctor-patient interaction, there is no hard evidence of suppression in terms of passive agent deletion in the data. Rather, the patient is portrayed as active agent, responsible for their actions. E.g.: Have you been using your drugs regularly (Hypertension, 12)

Doctors and patients have been using active verbs to describe situation in which they are agents. So suppression is not evidenced in the data. Since the patient and her condition are at the heart of the consultation, $1 \mathrm{t}$ is very difficult for her to be excluded from the discourse of the encounter. All agents of action (patient, doctor and illness e.g. you, 1 , and it) are not excluded. Hence, agentive participants are not excluded from the interaction. Beneficiaries (social actors who benefit from an activity) have also not been excluded

\section{Discussion and Conclusion}

The use of material processes by the doctor shows that $\mathrm{s} /$ he is highly interested in "facts, events and information so as to assess the patient's condition. Doctors' use of material processes shows their interest in the physical conditions of the patient. The use of relational processes assists the doctor in effective diagnosis since relational process types serve to 
identify and characterize (Halliday and Matthiessen, 2004). The use of mental processes also shows that the doctor is more involved in the mental condition or feelings of the patient because when a patient describes how s/he feels, thinks or perceives a problem situation, it helps the doctor to present a more appropriate diagnosis, prescription and treatment. This is because mental processes involved a Senser (a human agent who feels and thinks) and a phenomenon (a thing felt, thought or perceived). By using material and mental processes predominantly, the doctor is able to delve into the outer (material) and inner (mental) worlds of her patients thereby achieving one of the golden principles of holistic medicine - "medical treatment based on the belief that the whole person must be treated, not just the part of their body that has a disease" (Longman Dictionary of Contemporary English, Sixth Printing, 2012). While the doctor is the powerful discourse participant, he uses his power to the benefit of his clients through the judicious use of transitivity processes.

\section{References}

Adegbite, W. and Akin, O. (2006). Discourse Tact in Doctor-Patient Interactions in English: An Analysis of Diagnosis in Medical Communication in Nigeria. Nordic Journal of African Studies 15(4): 499-519.

Ainsworth-Vaughn, N. (1992). Topic Transition in Physician-Patient Interviews: Power, Gender, and Discourse Change". Language and Society 21: 409-26.

Ambady, N., Koo, J., Rosenthal, R. and Winograd, C. (2002). Physical Therapists' Non-verbal Communication Predicts Geriatric Patients' Health Outcomes" Psychological Aging 17(3): 443-452.

Byrne, P. S., and Long, B. E. L. (1976) Doctors Talking to Patients: A Study of the Verbal Behaviour of General Practitioners Consulting in their Surgeries. London: Her Majesty's Stationery Office

Eggins, S. (2004) An Introduction to Systemic Functional Linguistics. 2nd ed. London: Continuum

Fowler, R., Hodge, B., Kress, G. and Trew, T. (1979) Language and Control, London: Routledge and Kegann Paul Francis, G. and Kramer-Dahl, A. (1992). Grammaticalizing the Medical Case History In Toolan, M.(ed.) Language, Text and Context - Essays in Stylistics. London: Routledge, 1992: 56-90

Frankel, R. (1990) .Talking in Interviews: a Dispreference for Patient-initiated Questions in Physician-Patient Encounters. In G. Psathas, (ed) Interactional Competence Washington: University Press of America: 231-62

Freidson, E. (1970) Professional Dominance: The Social Structure of Medical Care New York: Athrton.

Gillham, B. (2000) Case Study Research Methods London: Continuum.

Gridley, H., Moore, S., Higgins, I. and Johnson, K. (1998). Improving Women's Health Care: The Experiences of Women Patients and General Practitioners in the Western Region of Melbourne. Australian Journal of Primary Health Interchange, 4, 119-113.

Halliday, M. (1985) An Introduction to Functional Grammar 1st Ed. London: Arnold.

------- (1994). An Introduction to Functional Grammar. $2^{\text {nd }}$ Ed. London: Arnold, Halliday, M. and Matthiessen, C. (2004) An Introduction to Functional Grammar 3rd Ed. London: Edward Arnold.

Heath, C. (1992). The Delivery and Reception of Diagnosis in the General-Practice Consultation in P. Drew and J. Heritage (eds), Talk at Work: Interaction in Institutional Settings. Cambridge: Cambridge University Press.

Jick, T. (1979). Mixing Qualitative and Quantitative Methods: Triangulation in Action" Administrative Science Quarterly 24 (December): 602-611.

Kress, G. (1990). Critical Discourse Analysis. Annual Review of Applied Linguistics, 11, 84-99.

Kurz, S., Silverman, J., Benson, J. and Draper, J. (2003) "Marrying Content and Process in Clinical Method Teaching: Enhancing the Calgary - Cambridge Guides. Academic Medicine, 78(8):802 - 809.

Lipkin, M., Jr., Frankel, R., Beckman, H., Charon, R.. and Fein, O. (1995) "Performing the Interview". In M. Lipkin Jr., S. M. Putnam, \& A. Lazare (eds.), The Medical Interview: Clinical Care, Education and Research. New York: Springer-Verlan: 65-82.

Odebunmi, A. (2003). Pragmatic Features of English Usage in Hospital Interactions Amongst Medical Practitioners and Patients in South-Western Nigeria. A Ph.D Thesis, Obafemi Awolowo University Ile-Ife

(2006). Locutions in Medical Discourse in South Western Nigeria" Pragmatics, 16(1), 25-41.

Ogunbode, O. (1991). Effective Communication in the Medical Sciences. In: E. Adegbija (ed.), Effective Communication in Teaching and Learning: Basic Principles Ilorin: Department of General Studies, University of Ilorin: 20-33.

Polimeni, A. (2006) Narratives of Women's Hospital Experiences: The Impact of Powerlessness on Personal Identity A Ph.D thesis, Swinburne University of Technology

Robinson, J. and Heritage, J. (2006). Physicians' Opening Questions and Patients' Satisfaction. Patient Education and Counseling, 60, 279-285. 
Ruusuvori, J. (2000) Control in the Medical Consultation: Practices of Giving and Receiving the

Reason for the Visit in Primary Health Care A Ph.D Dissertation, University of Tampere.

Savenye, W. and Robinson, R. (2004). Qualitative Research Issues and Methods: An Introduction for Educational Technologists In D.H. Jonassen 2004: 1045-1071.http://www.aect.org/edtech/ed1139. pdf.

Shimazumi, M. (1996) The Knower and the Informant in Institutional Talk: A Transitivity Perspective. An M.A Dissertation, University of Liverpool

Stubbs, M. (1983) Discourse Analysis: A Sociolinguistic Analysis of Natural Language Chicago: University of Chicago Press

van Leeuwen, T. (1996). The Representation of Social Actors" in Caldas-Coulthard, Carmen and Malcolm Coulthard (eds)

van Weel-Baumgarten, E. (2010). Person-Centered Clinical Practice. International Journal of Integrated Care Vol.10

van Dijk, T. (2009). Critical Discourse Studies: A Sociocognitive Approach in Wodak and Meyer

Ward, M. (2004). We have the power - or do we: Pronoun of Power in a Union Context. In Young and Harrison

Wolfram-Cox, J. and Hassard, J. (2005). Triangulation in Organizational Research: A Re-presentation Organization 12(1) 109-133

\section{APPENDIXES}

Hypertension (DOCTOR)

\begin{tabular}{|c|c|c|c|c|}
\hline$S I N$ & $\begin{array}{l}\text { AGENT (Actor acting } \\
\text { on things) }\end{array}$ & $\begin{array}{l}\text { PROCESS (Range) } \\
\text { (what happens) }\end{array}$ & $\begin{array}{l}\text { MEDIUM (Actor } \\
\text { acting or Goal being } \\
\text { acted on }\end{array}$ & $\begin{array}{l}\text { CIRCUMSTANCE } \\
\text { (when and where) }\end{array}$ \\
\hline 3 & & 's the problem & what & \\
\hline 5 & & do ... have & You (patient) & with it \\
\hline 9 & & $\begin{array}{l}\text { don't have } \\
\text { (any problem) }\end{array}$ & You (patient) & \\
\hline 10 & & is & more [drugs] & Here ... for you \\
\hline 12 & You (patient) & Have ... been using & your drugs & regularly \\
\hline \multirow[t]{2}{*}{14} & (You, patient) & Consider changing & your drugs & If it is not doing \\
\hline & & & & the work you want. .. \\
\hline 15 & us (doctor) & is for .. to write ... & the alternative & \\
\hline 16 & You (patient) & can ... afford & $\begin{array}{l}\text { a thousand five hundred } \\
\text { naira }\end{array}$ & per \\
\hline 18 & $\mathrm{I}$ (doctor) & would write & this drug Thiapril & for you (in that case ... \\
\hline 19 & You (patient) & use & it (drugs) & \\
\hline 20 & (You, patient) & let ... know & us (doctor) ... the effect & \\
\hline 21 & I (doctor) & want to change & you & from nifedripin to thiapril \\
\hline 22 & It (drug) & would cost & you & $\begin{array}{l}\text { about a thousand five } \\
\text { hundred naira a }\end{array}$ \\
\hline 23 & You (patient) & just go, buy & a month's dose & \\
\hline 24 & You (patient) & use & it (drug) & \\
\hline 25 & It (drug) .... & believe $\quad . . \quad$ would & $\mathrm{I}$ (doctor) & \\
\hline 30 & It (drug) & would not control & the urine & \\
\hline 32. & It & Is & ... a clause & \\
\hline 34 & & $\begin{array}{l}\text { would do } \\
\text { let ... try }\end{array}$ & $\begin{array}{l}\text { I (doctor) } \\
\text { me (doctor) }\end{array}$ & \\
\hline $\begin{array}{l}35 \\
36\end{array}$ & $\begin{array}{l}1 \text { [doctor] } \\
1 \text { [doctor] }\end{array}$ & $\begin{array}{l}\text { would give } \\
\text { see (how you do) }\end{array}$ & $\begin{array}{l}\text { you (zextril) } \\
\text { youjpatient] }\end{array}$ & with it alone \\
\hline 37 & You (patient) & could iust buy & one week or two weeks & If you do well with it \\
\hline
\end{tabular}




\begin{tabular}{|l|l|l|l|l|}
\hline 38 & I (doctor) & would write & $\begin{array}{l}\text { two weeks or one week } \\
\text { dose }\end{array}$ & \\
\hline 39 & You (patient) & can be using & that one & $\begin{array}{l}\text { If you can tolerate that } \\
\text { doing }\end{array}$ \\
\hline 41 & & $\begin{array}{l}\text { also claim (that it is } \\
\text { okay for diabetes) }\end{array}$ & people & \\
\hline 47 & You (patient) & do .. use & the Aldomet & How \\
\hline 49 & You & do ... still use & it (drug) & $\begin{array}{l}\text { how ... ar using it right } \\
\text { now }\end{array}$ \\
\hline 52 & You & 's & That &
\end{tabular}

Hypertension (PATIENT)

\begin{tabular}{|c|c|c|c|c|}
\hline SIN & $\begin{array}{l}\text { AGENT (Actor acting } \\
\text { on things) }\end{array}$ & $\begin{array}{l}\text { PROCESS (Range) } \\
\text { (what happens) }\end{array}$ & $\begin{array}{l}\text { MEDIUM (Actor } \\
\text { acting or Goal being } \\
\text { acted on }\end{array}$ & $\begin{array}{l}\text { CIRCUMSTANCE } \\
\text { (when and where) }\end{array}$ \\
\hline 4 & I (patient) & Just want to & my condition & Again \\
\hline 6 & & $\begin{array}{lll}\begin{array}{l}\text { don't have (any } \\
\text { problem) }\end{array} & \\
\end{array}$ & I (patient) & with it \\
\hline 8 & & $\begin{array}{l}\text { don't have (any } \\
\text { enough) }\end{array}$ & & \\
\hline 11 & & am & I (patient) & Afraid - \\
\hline 13 & I (patient) & Do & & even this morning \\
\hline 26 & & $\begin{array}{l}\text { is [the same thing that } \\
\text { would control } \\
\text { urine) }\end{array}$ & it (drug) & for diabetes \\
\hline 28 & You (doctor) & $\begin{array}{l}\text { know ... am having } \\
\text { (that } \\
\text { too) }\end{array}$ & I (patient) & \\
\hline 42 & & $\begin{array}{l}\text { thank (God that there } \\
\text { is no injury) }\end{array}$ & I (patient) & \\
\hline 43 & & $\begin{array}{l}\text { Would be (very sad) } \\
\text { may } \\
\text { take }\end{array}$ & that (injury) & \\
\hline 44 & It & $\begin{array}{l}\text { may } \\
\text { take }\end{array}$ & me (patient) & to another place \\
\hline 45 & & would feel (bad) & I (patient) & \\
\hline 48 & I (patient) & do & & \\
\hline 51 & You (doctor) & said ( ... should use it) & I (patient) & in the morning \\
\hline 53 & $\mathrm{I}$ (patient) & am just using & it (drug) & Formerly \\
\hline 63 & & $\begin{array}{l}\text { don't know } \\
\text { the } \\
\text { name }\end{array}$ & I (patient) & \\
\hline 65 & & $\begin{array}{l}\text { 's } \\
\text { (of this colour, } \\
\text { other one white) }\end{array}$ & It (drug) & \\
\hline 75 & & can be done & it (test) & Today \\
\hline
\end{tabular}

